\title{
FEDERAL REGULATION AND PROHIBITION OF TRADE WITH IRON CURTAIN COUNTRIES
}

\author{
Stanley D. MetzGER*
}

\section{INTRODUCTION}

American federal regulation and prohibition of trade with Iron Curtain countries can be discussed from many angles. There is the historical approach-how our present levels of trade restriction came about. There is the economic analysis-how efficacious these controls have been to accomplish whatever economic objectives they were or are thought to serve. There is the political assessment involving international politics-how the expansion, or maintenance, or contraction of trade regulation has served or serves our international political objectives of creating and maintaining the cohesion of the West against efforts in the East to frustrate a world striving to develop in diverse ways. There is the political assessment involving domestic politics-how the creation, expansion, maintenance, and contraction of trade regulation by the Administration in power is related to efforts by the political party out of power to make domestic political capital out of the level of trade regulation with Communist or Communist-dominated countries. And, finally, there is the military analysis-how does trade regulation in fact affect the military potential of putative enemies.

A truly adequate analysis of our regulation of trade with Iron Curtain countries would need to include and to combine all these approaches. Obviously this task is beyond the scope of this paper if something more than a series of declaratory propositions of doubtful utility were desired, wholly apart from problems of competence to perform it.

I propose instead to undertake a somewhat more manageable task, though one which may nonetheless be of some interest and importance. I should like to outline briefly the existing levels of our restrictions on trade with Iron Curtain countries; to indicate the extent to which they differ from those of our allies and friends in the West; to point out the extent to which our restrictions are imposed by Act of Congress or are merely authorized by Congress and thus can be changed by an administration without formal congressional participation; and finally, to indulge in some mild guesses as to future levels of our regulation of trade with Iron Curtain countries in view of the circumstances thus disclosed, and the fact that there has been on foot for some time progressive relaxation of trade restrictions which appears highly likely to continue. ${ }^{1}$

- A.B. 1936, LL.B. 1938, Cornell University. Professor of Law, Georgetown University Law Center. Author, International Law, Trade and Finance (ig62); Trade Agreements and the Kennedy Round (1964).

1 There is a growing literature on trade restrictions, but it is spotty; to my knowledge there is no systematic critical analysis of our restrictions affecting trade with all countries. A recent good, short 


\section{Present Levels of Restrictions on Trade with Iron Curtain Countries}

It is necessary to make distinctions, some quite sharp, within the general term, "Iron Curtain" countries, because United States trade regulation has done so. The Iron Curtain countries may be differentiated, for trade regulation purposes, into four groups: (I) Communist China, North Korea, and North Viet-Nam; (2) the U.S.S.R. and her European allies other than Poland; (3) Poland and Yugoslavia; and finally, (4) Cuba.

\section{A. The Communist China Group}

In the first group, (which also is foremost in terms of the degree of trade restriction), stands Communist China, North Korea, and North Viet-Nam. We have prohibited export and import trade with Communist China and North Korea, blocked their assets in the United States, prohibited persons subject to our jurisdiction to engage in financial transactions with their residents, forbidden U.S. flag vessels from plying to Communist Chinese ports, and forbidden others to use dollar currency or credits to finance trade with them since the Communist Chinese armed participation in the Korean conflict, beginning in December $1950 .^{2}$ Neither the embargo on all trade nor the freezing of assets and denial of financial transactions are required by the Export Control Act, on the one hand, or section 5(b) of the Trading with the Enemy Act, on the other; both statutes authorize the actions but neither requires them, and both give very wide discretion to grant licenses. As a matter of policy, however, we utilize the authority granted by these statutes almost to their limits and in fact have granted very few licenses.

Subsidiary trade discriminations, such as denial of most-favored-nation tariff treatment, ${ }^{3}$ and prohibition of sale of surplus agricultural commodities to them for local currency, ${ }^{4}$ both in the form of mandatory legislative prohibitions, followed in train,

description of American trade and financial restrictions, with emphasis upon the mechanics of export control, is found in AMERican Law Instrrute-American Bar Association, Joint Comm. on Continuing Legal Education, A Lawyer's Guide to International Business Transactions 56-92 (Walter S. Surrey \& Crawford Shaw ed. I963) [hereinafter cited as SURREY \& SHAw], together with a selected bibliography, id. at 98-100. A good comprehensive summary of restrictions on trade with the Soviet Union, as of 1959 , is contained in Berman, The Legal Framework of Trade Between Planned and Market Economies: The Soviet-American Example, 24 LAw \& ConTeMp. Prob. 482, 504528 (1959). The best descriptions of the levels of trade restrictions of the allies and friends of the United States can be found in the sixteen Battle Act Reports to the Congress, the reports of the Administrator of the Mutual Defense Assistance Control Act of 195I, 65 Stat. 664 (195I), 22 U.S.C. $\S$ I6II (1958).

${ }^{2}$ The embargo on trade with North Korea was invoked in June I950, I5 Fed. Reg. 4I89 (I950). It was extended to Communist China in December 1950, I5 Fed. Reg. 8563 (r950). Financial restrictions, including blocking of assets, were applied to Communist China and North Korea by Treasury Regulations issued December I7, I950, 3I C.F.R. $\$ \S 500.20$ I, 500.204 (I950).

${ }^{3}$ Sec. 5, Trade Agreements Extension Act of 195I, repealed, 76 Stat. 882; $§ 23 x$, Trade Expansion Act of 1962,76 Stat. 876, Ig U.S.C. $\$ 1861$ (Supp. IV 1962 ).

'Sec. roI of Pub. L. No. 480, 68 Stat. 455 (1954), as amended, 77 Stat. 390 (1963), 7 U.S.C.A. $\$$ I 0 I (Supp. I964), authorizes the President to riegotiate and carry out agreements with "friendly 
as well as strong steps in the direction of securing parallel action on the part of our allies. $^{5}$ In this latter effort we have had indifferent success, especially and progressively as time has lengthened since the Korean armistice of 1953.

At no time did other countries, even apart from the Soviet bloc, mount an cmbargo on China trade, with the exception of Nationalist China, and certain other countries of Southeast Asia, whose policy of embargo has been a matter more of form than of substance, given the range of their trade. There was, however, a "China differential" observed by the major world trading nations, in terms of greater restriction on trade with Communist China than with the Soviet European bloc, until I957, when our allies decided to eliminate the differential. ${ }^{\circ}$ And since the international list of goods which the western allies had agreed was to be denied to the Soviet European bloc had itself been curtailed in $1954,{ }^{7}$ and was further shortened in $1958,{ }^{8}$ this means that for the past seven years there has been a marked difference in the trading restrictions which the United States on the one hand, and the rest of the major trading nations of the Western world on the other, have maintained against Communist China, North Korea, and North Viet-Nam. We embargo; they trade in a wide range of both industrial and agricultural commodities."

We can be quite certain that barring new international hostilities involving force, our allies will not change the policy which they have pursued since the mid-I950s. A fair sample of their views was recently expressed in an article in the Washington Post of December 29, I963 under the headline, "Big Wheat Jubilee: Canada Just Keeps Selling Grain, Making Money," by Mr. G. V. Ferguson, editor of the Montreal Star. He said: ${ }^{10}$

The [U.S.] embargo on shipments to Red China has no counterpart elsewhere, and nobody outside the United States believes that the embargo has any merit, except as a gesture which they believe as not necessary to a sound foreign policy.

Certainly it can be taken for granted that Canada will sell its big wheat surplus to anyone offering reasonable deals and Trade Minister Mitchell Sharp's chief trouble is to find shippable wheat to meet the needs of long-standing customers in the face of a possible tendency to neglect the old unspectacular customers in favor of the big, new glamorous buyers behind the Iron and Bamboo curtains.

nations" to provide for the sale of surplus agricultural commodities for forcign currencies, and $\$$ I07 of that Act, 68 Stat. 457, 7 U.S.C. \$ I707 (1958), defines "friendly nation" as "any country other than (1) the USSR, or (2) any nation or area dominated or controlled by the forcign government or forcign organization controlling world Communist movement."

8 "The Strategic Trade Control System I948-1956," pp. 33-35, 9th Report to Congress by Administrator of Mutual Defense Assistance Control Act of r95I [hereinafter these reports will be cited as, e.g., "9th Battle Act Report"].

${ }^{6}$ r 4 th Battle Act Report, p. 5.

${ }^{7} 9$ th Battle Act Report, pp. 23-30.

${ }^{8}$ I4th Battle Act Report, pp. I-4.

"x6th Battle Act Report, pp. 65-69. This report states that, in 196r, "Free World" countrics exported $\$ 742.2$ million worth of goods to Communist China, and imports from Communist China amounted to $\$ 637.5$ million. Exports included food, chemicals, fibers, machinery, generators, transport equipment including ships, and so on, and imports ran the same gamut.

${ }_{10}$ The Washington Post, Dec. 29, 1963, p. E7. 
Britain sold six Vickers Viscounts to Communist China in Ig6I, and its trade delegation to Peking has been making strenuous efforts to increase trade over a spectrum of non-strategic goods. ${ }^{11}$ It has recently been reported that trade delegations from France, West Germany, Italy, Belgium, Sweden, the Netherlands and Japan have been in China to the same purpose. ${ }^{12}$ Last year, Communist China's favorable trade balance with Hong Kong reached a "record of \$230 million."13

\section{B. The Soviet European Bloc}

In the second group of Iron Curtain countries we find the Soviet Union, her Eastern European "satellites"-Hungary, Rumania, Bulgaria, East Germany, Czechoslovakia, and Albania and Outer Mongolia. We do not embargo exports and imports with those countries and areas. Rather we forbid those exports from the United States which we judge would make such "a significant contribution to the military or economic potential of" those countries that supplying them "would prove detrimental to the national security and welfare of the United States."14 And we seek to have our allies cooperate by joining in the denial to those countries of "strategic" goods-we know that our allies will not cooperate in denying goods which merely contribute to the "economic potential" of the Soviet Union and its European allies. ${ }^{15}$

United States export controls have never been employed to deny shipment of all types of commodities to the Soviet Union and the other countries in this group. For example, ordinary foods and fibers have never been denied licenses for export as such. ${ }^{16}$ On the other hand, not only have "strategic" goods-goods which contribute to the war potential of the Soviet bloc ${ }^{17}$-been denied exportation, but also such items as $\$ 100,000$ dollars' worth of carburetors for cars and trucks in Rumania, and $\$ 43.7$ million worth of automotive machine tools (\$2.3 for Czechoslovakia, \$4r.4 for the U.S.S.R.), have been denied export licenses, because such exports "would have contributed significantly to the automotive capacity of the bloc."1s

As indicated, this later type of export denial-goods which contribute to the "economic potential" of the "bloc"-has no counterpart in the export controls of our allies. And even as to strategic goods, their controls are not parallel with our own export control, since their view of what contributes substantially to the war potential of the Soviet Union is significantly more restrictive than ours. ${ }^{19}$

Any thought, however, that our export control statute is an inflexible instrument

${ }^{11}$ N.Y. Times, Jan. ${ }_{3}$, I964, pp. $\mathrm{C}_{37}, 47,55$.

${ }^{13}$ The Washington Post, Dec. 22, 1963, p. A23.

${ }^{13}$ Supra note Ir, at p. $\mathrm{C}_{47}$.

16 Sec. 3, Export Control Act of 1949 , as amended, 63 Stat. 7 (r949), as amended, 76 Stat. I67 (r962), 50 U.S.C. App. $\$ 2023$ (Supp. IV I962).

${ }^{25}$ x6th Battle Act Report, pp. 4-6, 7-8.

${ }^{10} 9$ th Battle Act Report, pp. II-r 4; I4th Battle Act Report, p. 49.

17 gth Battle Act Report, p. I2.

${ }^{18}$ 6Ist Quarterly Report (Third Quarter 1962) on Export Control by the Secretary of Commerce to the President and the Congress, p. 13.

${ }^{10}$ I6th Battle Act Report, p. 7 . 
is wide of the mark. As construed by the Department of Commerce, which administers it, the statute indeed allows for very great flexibility in application. I refer here to the interesting exegesis of the amendments made in 1962 to the Export Control Act contained in the 6rst Quarterly Report by the Secretary of Commerce (Third Quarter, 1962) on Export Control. For example, speaking of controls over goods contributing to the "economic potential" of the Soviet bloc, the Department of Commerce has indicated its approach to license applications in the following terms: $:^{20}$

When ... it is found that an item will contribute significantly to the economic potential of the Soviet bloc, it may or may not be detrimental to the national security and welfare to approve it. There is, of course, a burden on any one who would argue that there is no such detriment. One situation where this burden can at times be met is where the same item, or a close equivalent, is readily available to the bloc from other free world sources. The Department has in particular cases concluded that, under such circumstances, and assuming that the United States is unable to persuade other free world countries to refuse to export the item in question to the Soviet bloc, it should properly conclude that export of the item from the United States would not be detrimental to the national security or welfare. In such cases the Department has decided that as long as the bloc can get the same or a similar item elsewhere, it is the fact of acquisition and use by the bloc that affects the security and welfare-not the source of the export. And, when it is considered that denial under such circumstances only operates to the detriment of U.S. business firms and workers, the Department believes it is not unwise in concluding on balance that there is, in such cases, more detriment to the national security and welfare in denial than there is in approval. There is, of course, a "grey" area between the military and economic, where one may find an item that appears to contribute to both potentials, but contributes significantly more to the one than the other. Such items must, of course, be dealt with on a case-by-case basis, in the light of such factors as the relative degree of contribution to the military or economic potentials, and the relative degree of effectiveness of U.S. control.

Even as to an article which may contribute significantly to the military potential of the Soviet bloc, there must be, first, a decision by the Commerce Department that in fact it does so contribute, which in a very large area involves judgments fully capable of changing from time to time depending on changing military assessments of the article; and second, a decision that exportation would prove detrimental to the national security and welfare of the United States. The Department has been careful to give itself some room even as to this second question, since it says that "it would most likely deny" exportation of items which in its judgment did contribute to military potential because "it is very difficult to see how" approval would "not prove detrimental" to U.S. security and welfare. ${ }^{21}$

In addition, the Commerce Department has construed a recent amendment to the Export Control Act as authorization to it to "vary the scope and severity of export control to particular countries, from time to time, as national security and foreign policy interests require; e.g., during a period of heightened tension." As we shall

${ }^{20}$ Supra note I8, at 6.

${ }^{21}$ Ibid. 
see in regard to Poland, the Department has already varied the scope and severity downward in the reverse case-one of lessened tension.

Finally, the Commerce Department has read together two of the 1962 amendments in such a manner as to give it the very largest area of discretion in its choices of when to and when not to license. The first amendment was the third unnumbered paragraph in section 2 of the Act, ${ }^{22}$ reading: "The Congress further declares that it is the policy of the United States to use its economic resources and advantages in trade with Communist dominated nations to further the national security and foreign policy objectives of the United States." The second amendment was that to section $3(\mathrm{a})$, third sentence, ${ }^{23}$ which provides that "rules and regulations" shall provide for denial of export licenses "to any nation or combination of nations threatening the national security of the United States if the President shall determine that such export makes a significant contribution to the military or economic potential of such nation or nations which would prove detrimental to the national security and welfare of the United States." What the Commerce Department did was to read these together as follows: ". . . the Department regards the policy statement of this [the first] amendment as related to the policy expressed in the amendment to section $3(\mathrm{a})$ of the act [the third sentence], a finding of a trade advantage under the amendment to section 2 being one means, for example, of counterbalancing what might otherwise be a claim of 'detriment' under section 3(a)."24 If I understand this rightly, the Department is saying that the act allows it, in its discretion, to find that the advantage to American exports and balance of payments from the sale of carburetors counterbalances any detriment to the security of the United States flowing from an increase in the "automotive potential" of the Soviet Union, and hence to license the export. Nor is this reading limited to exports which makes a significant contribution to "economic potential."

As with Communist China, the Soviet Union and her European satellites are by law denied most-favored-nation tariff treatment-their goods pay the I930 Tariff Act rates, not the rates as reduced by trade agreements entered into since the 1934 Trade Agreement Act-and agricultural commodities cannot be sold to this group of Iron Curtain countries for local currency under the Agricultural Trade and Development Act-the P.L. 480 program.

Does this mean that our agricultural commodities cannot be sold to the Soviet Union at subsidized export prices-that is to say, at world prices, which are lower than our deliberately supported higher domestic prices? The Attorney General ruled in October 1963 , in connection with the then contemplated wheat transactions with the Soviet European bloc, that we could sell at the world price. ${ }^{25}$ The re-

${ }^{22} I d$. at 47 .

${ }^{23}$ Id. at 48 .

24 $l d$. at 5 .

${ }^{25}$ U.S. Attorney General's Opinion on Wheat Sales, Dep't of State Press Release 520, Oct. 10, 1963, 49 Dep't State Bull. 66r (1963); 2 International Legai Materials [hereinafter cited as I.L.M.] xrg4, 1 Ig8 (1963). 
striction in P.L. 480 is limited to a prohibition of sale for local currencies, e.g., for rubles, and does not apply to sales at world prices for dollars.

Are there financial or credit restrictions which hamper trade with the Soviet Union and her European satellites? We have not invoked section $5(\mathrm{~b})$ of the Trading with the Enemy Act respecting the Soviet Union and her European bloc (with the exception of an ad hoc blocking of one steel mill bought by Czechoslovakia) ${ }^{26}$ as we have with Communist China. This means that there is no blocking of Soviet assets in the United States, nor is there a general restriction upon the use of dollars or other currencies by persons subject to American jurisdiction or others for the financing of trade between the United States and the Soviet Union and her European satellites. There is, to be sure, a financial transactions control, ancillary to our own export control and to the multilateral strategic control system, which operates to prohibit the use of dollars in financing trade from third countries to the Soviet bloc of certain strategic items, but that is a quite limited control.

What about financing of trade through credits, of which we have been hearing quite a bit this past year? Are there legal restrictions on the granting of governmental credits to finance trade with the Soviet Union, or merely restrictions based upon policy considerations? Are there legal restrictions on private credit financing of trade with the U.S.S.R.? Are there legal distinctions between so-called short-term and long-term credits for this purpose?

The Attorney General's opinion of October 1963 answered a number of these questions. In the first place, the Johnson Act, ${ }^{27}$ which forbids certain financial transactions involving foreign governments in default in the payment of their obligations to the United States (i.e., the Soviet Union), is not applicable to the Government of the United States or to "public corporations created by or pursuant to special authority of Congress, or corporations in which the United States has or exercises a controlling interest through stock ownership or otherwise." This exception includes, for example, the Commodity Credit Corporation. Furthermore, it is not applicable to the Export-Import Bank, in view of the express exclusion from Johnson Act restrictions contained in the Export-Import Bank Act of $1945{ }^{28}$ hence the Bank may participate in export sales financing "by issuing a guarantee of payment of the purchase price or otherwise." Nor does the Johnson Act apply to "private insurance companies, acting through the Foreign Credit Insurance Association, which might participate with the Bank in the issuance of such guarantees."20

${ }^{26}$ A Lawyer's Guide to International Business Transactions, op. cit. supra note $\mathrm{I}$, at 86. After Czechoslovakia had jailed William Oatis, an AP correspondent, on spying charges, the United States forbade the export from the United States of a steel mill which had been purchased by Czechoslovakia for more than $\$ 16$ million, and paid for, and then ad hoc blocked the property in order to prevent Czechoslovakia from selling it and realizing the funds to use in other ways. No other Czech property was blocked, however, nor were transactions with Czechoslovakia, other than in this steel mill property, prohibited.

${ }^{27} 62$ Stat. 744 (I948), I8 U.S.C. $\$ 955$ (I958).

${ }^{28} 59$ Stat. 529 (r945), as amended, 12 U.S.C. $\$ 635$ h (I958).

202 I.L.M. II95. 
Secondly, sales by private American firms on a deferred payment basis are not "loans" to defaulting countries within the meaning of the Johnson Act; rather, they are "credits," which are not within the Johnson Act prohibitions. Further, discounting of commercial paper is not a "sale" of "obligations" under the Act, because the Act "relates only to sales of bonds and securities and 'other obligations' of like nature." 30 While the opinion dealt with proposed sales "on normal commercial terms," i.e., deferred payments up to eighteen months or so, this rationale by the Attorney General would appear to support the conclusion that private sales involving deferred payments over a longer term would also not run afoul of the Johnson Act, although there is no great practical likelihood of purely private trading transactions involving lengthy repayment periods, such as over five years.

The only other statute which might interdict credit financing of exports to the Soviet bloc is the Battle Act. This is the act named after a former Alabama congressman which supplements our Export Control Act by adding a mechanism for inducing other countries to embargo the shipment to the Soviet bloc of "arms, ammunition, and implements of war, atomic energy materials, petroleum, transportation materials of strategic value, and items of primary strategic significance used in [their] production." 31 The Battle Act provides for the termination of all military, economic, or financial assistance to any nation if it "knowingly permits the shipment to any nation or combination of nations threatening the security of the United States, including the Union of Soviet Socialist Republics and all countries under its domination," of any of the embargoed materials.

The Attorney General stated that this Act "did not purport to regulate private United States shipments to Soviet bloc countries, which were already subject to regulation under the Export Control Act." It "relates, rather, to trade with the Soviet bloc by countries receiving aid or assistance from the United States."32 This analysis, of course, also supports the conclusion that the Battle Act does not purport to regulate public or governmental United States shipments to the Soviet bloc.

"Moreover," said the Attorney General, probably for the benefit of those who might not be entirely convinced by this analysis," "the transactions to which this

${ }^{30} I d$. at 1196. It is interesting to note that Professor Berman stated in I959 that, "The term 'loan' in' the Johnson Act has been construed ... to apply to credits beyond six months," explaining that "This is the opinion of the Attorney General's office, as given informally in response to inquiries by American businessmen." Berman, supra note $I$, at 516 .

${ }^{31}$ Sec. ror Mutual Defense Assistance Control Act of I95r, 65 Stat. 644 (I95I), as amended, 22 U.S.C. $\$ \mathrm{I} 6 \mathrm{II}$ et seq. (I958).

32 I.L.M. II 199 .

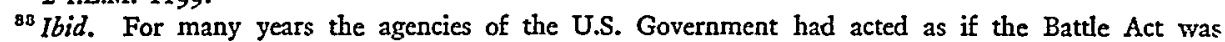
applicable to one Iron Curtain country which shipped arms, ammunition, implements of war or atomic energy materials to another, just as it was deemed applicable to, e.g., Denmark, were she to ship such goods to an Iron Curtain country. The language of the act itself makes no distinction-it refers to "any nation." The issue therefore was not whether the Battle Act applied to the United States, in the sense that the United States was to be put in the place of Denmark or Czechoslovakia, but rather whether what the United States contemplated continuing to provide to Denmark or Czechoslovakia-assuming that either shipped such proscribed goods to an Iron Curtain country-constituted "economic assistance." If what the United States provided, either in money or goods, was such "assistance," it must be cut 
opinion relates [wheat sales on deferred payment basis] would be purely commerical in nature from the standpoint of the purchasing countries, and would therefore not involve 'economic or financial assistance' within the meaning of the Battle Act." It is difficult to perceive that longer term credits, rather than shorter term credits, accompanying the sale of commodities for export would work a change in the "commerical nature" of the transaction, from the standpoint of the purchasing country. It would in both cases be purchasing commodities for dollars, in one case paying in a year and a half, in the other in five, six, seven, or ten years with greater rates of interest in most instances, and, in all such cases, paying more dollars. The Attorney General's opinion therefore appears to be saying that, however one views the purposes of the Battle Act, it does not prohibit the exportation of goods from the United States to the Soviet bloc on credit terms, long or short term, so long as the purpose of the transition is to exchange goods for desired and desirable American dollars.

If then, our legislation does not require us to refrain from extending credit financing in the exportation of goods to the Soviet bloc whether the exports are made through governmental instrumentalities or through private shipments, it is clear that whether we do or do not extend credits is a discretionary act of policy of our government. And, it might be added, none of the legislation we have been discussing distinguishes the Communist China group of Iron Curtain countries from the European Soviet Bloc.

What is our policy today on credits for financing trade? Since the Administration in the fall of 1963 announced willingness to extend governmental credits on "normal commercial terms," i.e., r8-month deferred payments, to the Soviet European bloc, and staved off strenuous efforts in the Congress to deny it the means to extend such credits, ${ }^{34}$ it must be taken that it is clear for the present, as it has not been hitherto, that our policy embraces short-term credit financing of American exports to the Soviet European bloc. On longer term credit financing-beyond five yearsit has also been made clear that our present policy is to refuse to offer such terms, and, beyond that, to seek to persuade our allies to refrain from offering such longerterm credit financing for their own exports. ${ }^{35}$

Here again, however, we appear to be running into difficulties which are unlikely to be surmounted short of a new outbreak of serious fighting. While the Federal Republic of Germany appears to be prepared to join us in non-extension of

off; if it was not, it could continue to be provided. It seems therefore that the Attorney General was greatly overstating the matter when he said that the Battle Act did not relate to United States cconomic relations with Soviet bloc countries. Assuredly it does not, if such relations do not include "cconomic assistance" to the foreign nation which is shipping proscribed goods to an Iron Curtain country.

${ }^{84}$ The President's communication of Oct. 10, I963, H.R. Doc. No. $16_{3}, 88$ th Cong., Ist Sess. (1963), related in detail why he considered it to be in the national interest to sell surplus agricultural commodities to the Soviet European bloc. Efforts thereafter to prohibit the use of apropriated funds for such purposes, by the adoption of the Mundt Amendment to the Foreign Assistance Act of $196_{3}$, failed by narrow margins. See Iog CoNG. REc. 19322 (1963).

${ }^{35}$ The Washington Post, Jan. 19, 1964, pp. Ar, 13. 
longer than five-year credit financing, it is clear that Britain will not, and therefore that France most likely will not. ${ }^{36}$ And if the recent past is any guide to the near future, this means that in all likelihood the smaller European trading nations-the Dutch, Belgians, Swedes, Italians-will not join us, because to do so might disadvantage their competitive exports. This likely development, in turn, might well lead to a prudent judgment that West Germany will not long remain a spectator of an over five-year credit financing parade, when one gets underway. ${ }^{37}$

C. Poland and Yugoslavia

When we turn to the third "group" of Iron Curtain countries: Poland and Yugoslavia, we find further variations in the regulation of trade. In fact, Yugoslavia is not considered to be a "bloc" country and needs discussion principally because successive Administrations' treatment of Yugoslavia has over the years encountered difficulty in the Congress.

In I957, after the Gomulka regime succeeded in asserting a marked degree of independence from Soviet domination and control over its internal affairs, we lowered the level of our control of exports to Poland. ${ }^{38}$ In addition, beginning in $195^{6}$ the Administration found that Poland was no longer dominated or controlled by the Soviet Union within the meaning of P.L. 480 and thus was enabled to make

${ }^{80}$ Ibid. The Washington Post, Jan. 9, I964. The British are negotiating a long-term credit with the U.S.S.R. for the sale of a chemical plant worth about $\$ 30$ million, according to Flora Lewis, reporting from London to the Washington Post. She reports that the dispute with Washington over this question "is not just a dispute over tactics, but reflects basic and far-reaching differences of attitude on the key question of how to press the effort to taper off the Cold War." The British are in disagreement with the Central Intelligence Agency's recently publicized analysis that Russia is faced with a choice "between guns and butter unless the West provides up to $\$ 500$ million a year in long-term credits." Moreover, "they do think a ban on long-term credits for America's reasons would be taken by the Russians as a form of economic warfare and put them more angrily on guard."

"The British not only disagree that a lean Russia would be less bellicose and more interested in negotiating with the West, they consider that there is a serious risk that if economic troubles get out of hand Moscow will revert to Stalinist-type belligerence. Hostile foreign relations have usually accompanied the need for strong domestic suppression of discontent.

"Therefore, the British hold that a fat Russia is in the interests of the West. They do not claim that a prosperous Russia is bound to be more docile. They consider it a possibility, and they are frankly interested in the huge trading opportunities that a prosperous, industrialized Soviet Union could offer."

It is obvious that there are no hornbook answers to this kind of question. It is equally obvious, however, that the British argument is, at the least, sufficiently strong to withstand efforts to change British policy. In this connection it is of interest to note that the latest (I6th) Battle Act Report states that while economic sanctions served as a "marginal restraint" on Soviet aggressive capabilities during the tension of the Stalin and early post-Stalin years, "the inevitable process of industrial and economic growth during these 12 years has meant that the Soviets have developed their own productive capability in many of the areas where a restraining impact was necessary and possible ro years ago" (at p. 8). [Since the above was written, the British concluded the sale, involving a 15 -year government guaranteed credit.]

${ }^{37}$ Flora Lewis has reported, in connection with the German position:

“. . . the British ask a little tartly, has the United States not noticed that West Germany has two outstanding long-term credit agreements with the Russians? One is for ships for 6 years, the other for a polyethylene plant for 8 years. Both are backed by provincial government guarantees, approved by the federal government, which is the German explanation of why they do not count as a breach by Bonn itself of America's recommended 5-year limit." The Washington Post, Jan. 19, 1964, p. A r $_{3}$.

${ }^{88}$ 4Ist Quarterly Report on Export Control, p. 3. 
a series of agreements for sales of surplus agricultural commodities to Poland for local currency. ${ }^{39}$ The Administration was required to defeat efforts in the Congress to reverse its finding and hence to stop the sales, but it did so handily. ${ }^{30 n}$ Thereafter, in I 600 , the Administration, making the same finding-that Poland was not so dominated or controlled-for the purposes of the Trade Agreements Act, accorded mostfavored-nation tariff treatment to Poland at the same time as it secured Polish agreement to make a deferred-payment lump sum compensation agreement on account of Polish nationalizations of American-owned property in Poland. ${ }^{40}$

In 1962 the Congress, over strenuous Administration objections including the personal participation of the American Ambassador to Yugoslavia, provided in the Trade Expansion Act ${ }^{41}$ for denial of most-favored-tariff treatment to Poland and to Yugoslavia (which had never before been denied most-favored-nation treatment) "as soon as practicable." In I 963 , however, further strenuous Administration efforts to delete this prohibition, through an amendment in the foreign aid legislation, ${ }^{42}$ succeeded, with the result that both Poland and Yugoslavia continue to receive mostfavored-nation tariff treatment.

As has been indicated, the other legislative enactments authorizing restrictions on trade with Poland, with or without credit financing, permit a very high degree of discretion in the determination whether and to what extent trade should be restricted. In fact, there is no asset-blocking or financial transaction control, ${ }^{43}$ and short-term credits are permitted. Moreover, our no over five-year credit financing policy is not applicable to trade credits to Poland.

So far as Yugoslavia is concerned, it is treated for export control purposes as a Western European country.

The reason for this, as well as for the absence of other trade or credit restrictions, ${ }^{43 a}$ and for the substantial American aid program to Yugoslavia, is of course

${ }^{80}$ The first of the series was signed and entered into force on' June 7, 1957, T.I.A.S. No. 3839.

${ }^{302}$ The Administration fared less well in the second session of the Eighty-eighth Congress, in 1964 , an election year. Sec. II of Public Law No. 88-638, the act extending Public Law No. 480 authority, forbids sales of surplus agricultural commodities for local currency to Poland and Yugoslavia, though permitting dollar sales on five year credit terms. Needless to say, the Administration opposed this provision, and may be expected to press for its elimination in the next Congress.

to Agreement Relating to Settlement of Claims of Nationals of the United States Against Poland and Exchange of Notes, July 16, 1960, T.I.A.S. No. 4545, II U.S.T. \& O.I.A. I953.

${ }^{12}$ Sec. 23r. While the Act itself did not specifically mention Poland and Yugoslavia, the House Committee Report made very clear the congressional intention that they be denied most-favored-nation benefits. H.R. Rep. No. 18I8, 87th Cong., 2d Sess., 4, 40-4r (I962).

${ }^{2}$ Sec. 402 of the Foreign Assistance Act of 1963 (P.L. 88-205) amended $\$ 231$ of the Trade Expansion Act of 1962 (P.L. 86-735) by adding a new subsection thereto reading as follows: "The President may extend the benefits of trade agreement concessions made by the United States to products, whether imported directly or indirectly, of a country or area within the purview of subsection (a) which, at the time of enactment of this subsection, was receiving trade concessions, when he determines that such treatment would be important to the national interest and would promote the independence of such country or area from domination or control by international communism, and reports this determination and the reasons therefor to the Congress."

${ }^{*}$ Other than the control over third country financing with dollars of trade in certain limited strategic goods.

isa See note 39 a supra. 
the fact that Tito broke with the Soviet Union in I948 and is not in military alliance with the Soviet Union through the Warsaw Pact, and that the United States is satisfied that Yugoslavia has not since 1948 again become, in sum, a member of the bloc. The Administration's maintenance of this assessment, with its consequential results, has not been free from efforts in the Congress to upset them, but these efforts have been successfully repulsed. ${ }^{44}$

Almost needless to say, our allies and friends have been trading with Poland and Yugoslavia in a wide range of goods, involving substantial credits, for many years.

\section{Cuba}

American regulation of trade with Cuba began in I960. Restrictive licensing began in the summer of that year and, effective October 19, I960, exports of everything except certain foods and medical supplies were required by Commerce Department regulations, issued pursuant to the Export Control Act, to have validated export licenses, and the Department announced that no such validated licenses would be issued.

Although there was almost continuous consideration given to imposing controls over imports from Cuba, no controls were imposed until February 6, Ig62, when the Cuban Import Regulations, ${ }^{45}$ issued pursuant to the authority granted in section 620(a) of the Foreign Assistance Act of $196 \mathrm{I}^{46}{ }^{46}$ were issued. These regulations prohibited the importation into the United States of all goods of Cuban origin and all goods imported from or through Cuba, except pursuant to licenses, which as a matter of policy have not been issued. As originally issued, the regulations did not apply to imports of goods manufactured in third countries containing Cuban components, but on March 23, I962 they were amended to bar entry of such goods as well. The amended regulations were issued under the authority of section 5 (b) of the Trading with the Enemy $\mathrm{Act}^{47}$ as well as the aforementioned section of the Foreign Assistance Act of $\mathrm{Ig} 6 \mathrm{I}$, in view of the narrower scope of authority contained in the latter act. The reason for these import restrictions was stated to be that "the embargo will deprive the Government of Cuba of the dollar exchange it has been deriving from sales of its products in the United States," which, in turn "will reduce the capacity of the Castro regime, intimately linked with the Sino-Soviet bloc, to engage in acts of aggression, subversion, or other acts endangering the security of the United States and other nations of the hemisphere." 48

\footnotetext{
"4 See rog Cong. Rec. 20 III-I2 (I963).

4t 3 I C.F.R. $\$ \$ 515.101-515.801$ (I962). A good summary of trade restrictions with Cuba is contained in Surrey \& SHuw, op. cit. supra note $\mathrm{I}$, at $9 \mathrm{r}-92$, from which this and the next following paragraph are drawn.

${ }^{80}$ Sec. 620(a) of the Act, 75 Stat. 444 (I96r), as amended, 22 U.S.C. $\$ 2370$ (Supp. IV, I962) provided: "No assistance shall be furnished under this Act to the present government of Cuba. As an additional means of implementing and carrying into effect the policy of the preceding sentence, the President is authorized to establish and maintain a total embargo upon all trade between the United States and Cuba."

17 to Stat. 4 II (IgI7), as amended, 50 U.S.C.A. App. $\$ 5$ (b) (I962).

${ }^{48}$ Supra note 45 , at $9 x$.
} 
The Cuban Import Regulations apply only to importations into the United States and to financial transactions incident thereto. Unlike the financial controls applied to Communist China, they do not apply to other financial transactions with Cuba, nor to American citizens or American subsidiaries located abroad unless the transaction involves an importation into the United States.

Other trade controls applied to Cuba include denial of most-favored-nation tariff treatment, as well as the preferential rates under the 1902 Convention and the exclusive agreement supplementary to G.A.T.T., ${ }^{40}$ pursuant to the requirement of section 40I of the Tariff Classification Act of $1962,{ }^{50}$ until the President determines that Cuba is no longer controlled by the foreign government or foreign organization controlling the World Communist movement. Obviously no credits or other facilities affecting trade are available to Cuba in view of our almost total embargo.

Our allies and friends in the West do not embargo exports to or imports from Cuba. In early January 1964 this divergence in policy was made apparent when the United States objected to a British sale under government-guaranteed credit of some \$ro million worth of buses to Cuba, and the British Government and press rejected our efforts to stop the transaction. The British press was rather sardonic and mocking in the process. ${ }^{31}$ Other Western European countries such as France and Spain, as well as non-Soviet bloc countries elsewhere, also trade with Cuba in a range of products, which is currently being expanded both as to type of goods and quantities.

\section{II}

\section{Future Levels of Restrictions on Trade with Iron Curtain Countries}

Any attempt to guess, however carefully and mildly, concerning future develop. ments in American restrictions and prohibitions of trade with Iron Curtain countries must be based upon certain assumptions. If those assumptions are upset by events, so are the guesses; in fact, the guesses may be inaccurate in any event. With that exculpatory clause out of the way, one may hazard the future from the recent past on the single assumption that the various Iron Curtain countries and the various countries in the West will not engage in serious new fighting involving each other, directly or by proxy.

${ }^{40} \mathrm{Sec} \S 350(\mathrm{~b})$ of Tariff Act of 1930 , as amended, I9 U.S.C. $\$ 1350$ (b) (1960); for the 1902 Convention, 33 Stat. 2136, T.S. 427, I Mazloy 353; for the 1947 Exclusive agreement, 6I Stat. 3699 , T.I.A.S. No. I703, I19 U.N.T.S. I63.

${ }^{50}$ In addition, certain shipping controls have been applied to vessels which ply to Cuban ports. No shipments of cargoes financed by the Departments of State, Defense, Agriculture, the General Serviccs Administration or the Agency for International Development may be made on a foreign llag vessel if such vessel has called at a Cuban port on or after Jan. I, 1963 unless the person controlling the vessel assures that henceforth (from Dec. $x 6, x 963$ ) or as early as possible following expiry of charters entered into prior to that date, it will not so ply. "Cuban Shipping Policy," Dec. I6, I963. Morcover, $\$ 301$ (c) of the Foreign Assistance Act of 1963,77 Stat. 379 (1963), 22 U.S.C.A. \$2151 (Supp. 1964), cuts off aid to any country which fails to take "appropriate steps" to prevent its vessels from carrying goods to or from Cuba.

${ }^{52}$ The Washington Star, Jan. 9, 1964 ; The Washington Post, Jan. 13, 1964; N.Y. Times, Jan. $11,1964$. 


\section{A. Communist China}

Since our allies and friends have been engaging in trade with Communist China in a wide range of goods for some time and show no signs of changing that policyin fact, are intensifying efforts to expand their trade with China-it seems only a matter of timing dictated primarily by our domestic political considerations on the one hand, and intra-bloc relations on the other, before the United States will be prepared to relax its total embargo. This relaxation, when it occurs, will in all likelihood begin with licenses for the sale, for dollars, of wheat, and other grains which we have in substantial surplus, at world prices and for cash or on short credit "on normal commercial terms." Whether in fact we will be able to cut into the Canadian wheat market in Communist China is a question of some seriousness.

As evidence that this qualifies as a careful and rather mild guess, there is offered. the third of ten different ways outlined by President Johnson in his State of the Union Message of January 8, 1964 " to achieve "a world without war, a world made safe for diversity, in which all men, goods and ideas can freely move across every border and boundary." President Johnson's third way is: "Third, we must make increased use of our food as an instrument of peace, making it available-by sale, trade, loan or donation-to hungry people in all nations which tell us of their needs and accept proper conditions of distribution." These words-hungry people in all nations--must have been very deliberately chosen. Nor would it appear that there would be special conditions of distribution if there were dollar sales of wheat and other grains; at least I am not aware that there have ever been special distribution conditions imposed on dollar cash sales, as of course there have been on disaster relief grants or local currency sales.

Such a relaxation would not of course affect the existing status of non-recognition of the Communist Chinese régime, any more than did our commercial dealings with the Soviet Union before 1933. And it is probable that the licenses would issue to American private traders, enabling them to engage in such trade with Communist China, as in the recent wheat sale to Russia, so as to avoid directly dealing through the Commodity Credit Corporation.

Thereafter, over a longer time period, we would likely move toward trade in other "peaceful goods," since both the material and non-material reasons for not doing so tend to grow continually thinner as time goes on and our Western allies continuously step up their trading pace.

So far as most-favored-nation treatment and P.L. 480 sales for local currency are concerned, the prognosis is for no change for a very long time to come. In the absence of a substantial change in the character of the present Chinese régime, which hardly appears foreseeable, alteration of the status quo in these respects would require congressional action. And if there is any certainty remaining in domestic politics, it is that any Administration knows how difficult it is to ask Congress to

${ }^{52}$ H.R. Doc. No. $25 \mathrm{r}$, 88th Cong., 2 d Sess. $x 964$; The Washington Star, Jan. 8, x964, p. A-8. 
amend existing law if the effect of the amendment can be characterized as "helping the Communists," and avoids requesting such action if it is humanly possible to do so. The reasons for this are fairly obvious. The total foreign trade of the United States, imports plus exports, amounts to about $\$ 35$ billion a year, out of a gross national product of over $\$ 600$ billion a year. Using pre-trade restrictions and pre-war figures, in an effort to get to a "representative" year, those from 1938, we find that our foreign trade, imports plus exports including re-exports, with the whole SinoSoviet bloc amounted to the grand total of $\$ 309,877,000-$ a little over $\$ 300$ million. ${ }^{50}$ This amounts to less than one per cent of our total foreign trade, and an infinitesimal fraction of our gross national product. Is it any wonder that a Congressman hesitates to take the political risks involved in primary and general election campaign attacks on him for being soft on Communism, when there is so little domestic political capital in it for him on the other side? In I962 even so entrenched a Congressman, and one so seemingly impervious to such attacks, as the late Chairman of the House UnAmerican Activities Committee Francis E. Walter found himself charged with proCommunism because he led the congressional battle to provide continuing aid to Yugoslavia. It may also be recalled that there are many aspirants to political office who have made careers on such issues.

Since it is not hard to avoid going to Congress in the case of Communist China, I would therefore expect that it will be avoided.

\section{B. The Soviet European Bloc}

Here again, the prognosis is for steady but unspectacular relaxation of trade controls, not primarily in those goods which we consider to be strategic while our allies do not, but rather in the range of commodities which we do not restrict for that reason, but because they contribute to the "economic potential" of the bloc. There is, of course, no prospect for relaxation on arms, ammunition, implements of war, or atomic energy materials.

As we have seen, our allies apply no trade restrictions on goods which they consider non-strategic and have no intention of doing so. The Commerce Department's careful explanation of its reading of the 1962 Amendments to the Export Control Act as permitting export licenses for goods which the bloc can secure anyway in adequate quantities from our allies, must presage willingness to grant licenses when restriction "only operates to the detriment of U.S. business firms and workers."

In fact, in the summer of 1963 , the able Director of the Mutual Defense Control Staff of the Department of State, Robert B. Wright, underlined this relaxation in policy:

In cases where we cannot persuade other potential supplying countries to exercise an embargo policy and where the United States cannot be certain of withholding something

${ }^{83}$ I 4 th Battle Act Report, p. 48. 
from the Soviet bloc under unilateral controls that cannot be alternatively supplied by other countries, there seems a prima facie case for allowing United States traders to compete with other potential Western suppliers to the Soviet bloc. ${ }^{54}$

As these relaxations occur, and even before (as in the case of food and fibre exports), credits facilities in connection with such exports may gradually extend even beyond eighteen months-up to five years.

None of these changes would involve formal congressional participation.

As for not granting credits beyond a five year term, while our present efforts to secure parallel action from our allies are not meeting with success, and the augury for the future is the same, it is nevertheless unlikely that we would do an about-face any time soon. Quick political about-faces are ungraceful, and not enough turns on this one anyway. Thus, there will likely develop a "Soviet credit differential" over the next year or two, which will persist for some time.

So far as most-favored-nation tariff treatment and PL. 480 sales of surplus agricultural commodities for local currency are concerned, the prospects again are for no change in the near future, since both would require congressional action which any Administration will prefer to avoid.

I would offer only one possible caveat on this prognosis, applicable only to mostfavored-nation treatment. Suppose the United States ever resumes once again Lend-Lease settlement negotiations with the Soviet Union, the last explanation of positions having occurred in January 1960 , and these negotiations could result in a substantial cash payment by the Soviet Union over a period of years, paralleling the British and French Lend-Lease settlements. The atmosphere would then have been created for a strenuous Administration effort to secure from Congress a resumption of most-favored-nation treatment of Russia. For then the Soviet Union could point out that it needed to export more to us to earn the dollars to pay the installments called for by the settlement. In fact, I have been wondering for some time now why we have not suggested a resumption of Lend-Lease negotiations. We and the Soviet Union have been making a variety of suggestions to each other which might lower the temperature of the Cold War, and have accomplished successfully several of them. Can't we now make one which would help to liquidate World War II and also assist in re-establishing trade relationships beneficial to the American consumer?

\section{Poland and Yugoslavia}

Nothing much need be added to what has been said about these countries. It can be expected that relaxation of trade restrictions with Poland, which are not serious, will continue. Yugoslavia likewise, on the assumption that her basic political stance continues, can expect to continue to trade normally.

It is very possible that some of the other so-called satellite countries may in the

sc "The State Department Role in East-West Trade Controls," address before Ninth Annual Corporate Lawyers' Institute, University of Wisconsin, Madison, Wis., July I8, 1963, p. 7 . 
future be given treatment more comparable to Poland than to the U.S.S.R. in the interest of encouraging more diversity and semi-independence within the Soviet European bloc. Developments in Rumania ${ }^{54 a}$ and Hungary particularly point in this direction, but there are also indications of increasing interest in improved relations with the United States in all the European bloc countries except Albania and East Germany.

\section{Cuba}

James J. Walker, "Hizzoner" the Mayor of New York, once replied to a reporter who asked what he thought about the suppression of James Joyce's Ulysses: "I never knew a girl who was ruined by a book." While few of us possess or profess the expertise about overthrow of governments which "Hizzoner" was reputed to have concerning his avocations, it nevertheless seems safe to say that none of us have ever known of or heard about a government that was ruined by a partial embargo such as now exists respecting Cuba.

With Cuba trading with the Soviet bloc and Communist China, and increasingly with Britain, France, Spain and many others, it is obvious that the U.S. embargo is not going to bring Castro down, or even interfere materially with his acquisition of money with which to attempt to subvert Latin American governments. If he falls, or desists in these efforts, or both, it is more likely to be because of his domestic economic policies, which appear to have been inept these past five years, if Theodore Draper's article in Commentary ${ }^{\mathbf{5 5}}$ is any guide.

Nonetheless, it is most unlikely that because our embargo has had and will continue to have an extremely limited effect upon Castro's retention of power or trouble-making activities ${ }^{56}$ it will be changed any time soon. For our position of antipathy to Castro is staked out too firmly for the limited effects of our embargo to exercise real influence upon its continuation. As I have been indicating in various ways throughout this paper, domestic American politics has always had great motive power in causing the imposition as well as the retention of trade restrictions, and this has been true in Cuba's case as much as in that of Communist China. The cry, "don't just stand there, do something," when it becomes strident, results

ssa Subsequent to the writing of this article, the United States and Rumania discussed "economic and trade matters" during May I8-June I, 1964. The joint communique of June I (Dep't of State Press Release No. 263, June I, 1964), states that "The United States Government agreed to establish a Gencral license procedure under which most commodities may be exported to Rumania without the necessity for individual export license. In addition, the United States agreed to grant licenses for a number of particular industrial facilities in which the Rumanian delegation expressed special intercst."

BE 37 Commentary 25 ( 1964$)$.

${ }^{68}$ I6th Battle Act Report, p. 6, indicates that the large drop in Cuba's foreign trade was in part made up by U.S.S.R. trade and aid agreements. Recent activity, such as the bus deal with the United Kingdom, and the truck deal with France, indicates that Cuban foreign trade is now on the upswing.

${ }_{87}$ The Washington Post editorialized on Jan. 13, 1964, p. A I4, as follows:

"The dispute over trade with Cuba is another sign that the old simple world has vanished. Who would have thought that Generalissimo Franco, who asserts that he saved Spain from communism, would turn out to be a trading bedfellow with the Communist regime in Cuba? Spain is importing sugar from Cuba, and is giving serious consideration to an order for too ships for Mr. Castro's fleet. 
in trade restrictions being imposed by Administrations, all of which are well aware that this "something" is usually very, very little, and in their being retained long after even these marginal effects have practically evaporated.

Thus, the present differences in trade restrictions with Cuba, as between the United States and our allies, seem destined to continue for the foreseeable future. This difference in trade restriction in turn reflects differing political assessments concerning Cuba, which again reflects the degree of concern felt by the various allies regarding the actions of Cuba's government.

\section{Conclusion}

If one may be permitted to generalize upon the foregoing, the following propositions would appear to be justified:

I. At present, American restrictions on trade and credits in and of trade with the U.S.S.R. and the European Communist bloc, with Communist China and her sphere of countries, and with Cuba are more severe than the restrictions of our friends and allies.

2. The restrictions of many of our friends and allies upon trade and credits with all of these Iron Curtain countries are being progressively relaxed, and trade between them is growing, with all parties taking strong initiative in that direction.

3. With the exception of most-favored-nation tariff treatment, P.L. 480 sales of surplus agricultural commodities for local currencies, and shipping restrictions on Cuba, the differences in the levels of trade restriction between the United States and its friends and allies are the result of policy determinations, not mandatory as a matter of law.

4. The imposition and the maintenance of these more severe restrictions by the United States has been very largely the result of domestic pressures upon successive Administrations which, without regard to the particular political party in power at the time, have attempted with much success to retain as much legal flexibility as possible in order to be able to relax restrictions as circumstances permit from time

And the Spaniards are downright annoyed that the United States has formally complained about this alliance between Europe's loudest anti-Communist and Cuba.

"In Great Britian, a similar dispute is arising over a xo-million-dollar order for buses that Cuba urgently needs. The British, too, are irked with U.S. criticism. 'The United States has a surplus of wheat,' one Briton was quoted as saying, 'We have a surplus of buses.'

"These differing views over trade wtih Cuba are natural, since the embargo is justified primarily in terms of hemisphere and national interest. Cuba's neighbors have deep grievances against the Castro regime. But countries that are not parties to the dispute find it hard to understand why they should be bound by the embargo-particularly when the issues do not seem to them quite so black and white as they tend to appear here.

"In fact, the embargo has been chiefly a negative policy, dictated in part by a desire to 'do' something about Cuba. Though the embargo has hurt Castro, it has also provided him with a propaganda excuse for all the troubles that beset his country. Rather than weaken Cuba's dependence on the Soviet Union; the embargo has strengthened the very connection that this country finds most objectionable.

"In the absence of a better policy, and in the circumstances of an election year, the Cuban embargo may still make negative sense-it is a less reckless way of expressing hostility to Castro than organizing an invasion. But Americans should not be surprised when other countries have their own views on the wisdom of the policy." 
to time. All of these Administrations have been acutely aware of the limited effects which trade restrictions have had and have upon putative enemies.

5. All Administrations have also been acutely aware of the complications in our relations with our friends and allies-of the divisive effect caused by differences in our respective levels of trade restrictions with Iron Curtain countries.

6. In consequence of these circumstances, it may be expected for the near future that, apart from Cuba, within the tolerances deemed to be afforded by domestic politics, there will be progressive relaxation of our trade restrictions with Iron Curtain countries. But because our domestic tolerances will continue to be deemed to impede such relaxation, there will continue to be a differential between our trade restrictions and those of our allies, as both continue to reduce trade restrictions, and hence this source of friction in our relations will continue to exist. The United States may be expected in the future, however, to play these differences down rather than up, which has not always been the case in the past, including the recent past. 